\title{
Effect of Cooperative Learning Approach on Students' Academic Achievement in English in Co-Educational Public Secondary Schools, Nakuru County, Kenya
}

\author{
Vitalice Sonoi Makini ${ }^{1}$, \\ Doctorate Student in in Education (Curriculum \& Instruction), Kabarak University. \\ Fred S. Barasa ${ }^{2}$, \\ Professor of Education, Taita Taveta University. \\ Bernard Chemwei ${ }^{3}$ \\ Director ODELT and Teaching Practice Coordinator, Kabarak University.
}

\begin{abstract}
A lot of scholarly research articles have lauded the positive significant contribution of Cooperative Learning Approach (CLA) and its effect on student's academic achievement. However none of those studies have been conducted on English subject, therefore this study investigated how the use of CLA affects students' academic achievement in English in public coeducational secondary schools in Nakuru County. The study adopted quasi experimental design, based on Solomon Four- group, Non-equivalent Control Group Design. The study involved two Experimental groups, $E_{1}$ and $E_{2}$ which were taught through CLA method and two Control groups, $C_{1}$ and $C_{2}$ which were taught through the Conventional methods. The target populations were students and teachers from the four co-educational public secondary schools of Nakuru County. The accessible population was 766 form three students in the four schools. The study sample size was 242 Form three students from the four coeducational public secondary schools in Nakuru County. The study used English Achievement Test (EAT) to collect quantitative data. Data was analyzed using both descriptive and inferential statistics using the Statistical Package for Social Sciences (SPSS version 24). Comparing the mean gain for the two groups of students', it was established that students using cooperative learning approach were $12 \%$ higher in English achievement test as compared to their peers who were taught using conventional methods. The study concluded that there was statistically significant effect of cooperative learning approach on students' achievement of English in public coeducational secondary schools in Nakuru, County Kenya $(F(1,216)=113043.974, p<0.05)$. The study further concluded that use of cooperative learning approach improves student achievement in English compared to use conventional methods. The study recommended teachers to adopt modern constructivism approaches to teaching students especially Cooperative learning approach that is student centered.
\end{abstract}

Keywords: Cooperative Learning Approach, Academic Achievement

DOI: $10.7176 /$ JLLL/64-07

Publication date: January $31^{\text {st }} 2020$

\section{Introduction \\ Background to the study}

English as a service channel for teaching in Kenyan schools is an indispensable discipline both in educational programmes and as a utility subject (Barasa, \& Mutitu, 2013). The functions of English are varied, among them being; fulfilling educational, developmental, social, aesthetical aspects and cognitive development. A wide command of English knowledge and word power for different uses such as professional, economical daily transactions in the Kenyan and international world environment. In Kenya, elements of grammar and literature are integrated and taught as one subject namely, English. The components of the integrated English include; grammar items, comprehension passages, cloze test, poetry and poem appreciation, oral literature genres, and literature set books.

The poor language prowess of English by secondary school learners in the last three decades has shone the limelight on the instruction and studying of English Language. Specifically in Nakuru County where the study was based, the average mean score in English in 2017 of 3.00 out of a possible 12 points which translated to $25 \%$ was lower than the National mean score of $40.29 \%$ which was a negative drop of $15.29 \%$. Therefore, it was against this backdrop of information that this research study sought to fill the knowledge gap and investigate on the effects of using Cooperative Learning Approach on students' academic achievement in English, in coeducational public secondary schools, in Nakuru County (KNEC, 2018).

This poor results in English subject could be due to the instructional methods. Page (2017) established that CLA activities had many functions in learning activities for instance it gave a lot of learners a chance to 
operate in cohorts, work and discuss in groups and ensured that all team members did everything from lesson planning and solving difficult challenges together. Sharan (2018) found that learner's collaboration promoted constructiveness and inspired students to learn unlike in competition strategies. Pandya (2017) found out that cooperative learning methods encouraged constructive feelings towards both instructional and active methods of instructing science, and that learners exposed to cooperative strategies believed that they gained a lot from its lesson content unlike learners exposed to conventional approaches for instance competitive methods. This therefore warrants the use of cooperative learning approaches in teaching of learners.

\section{Statement of the Problem}

The role of English language in Kenya's education system is crucial and central in shaping students' careers and facilitating their economic, political and social interactions in the society. However, it's importance is overshadowed by students low achievement in English annually in National Examinations as is evidenced by the KNEC (2018) reporting a constant mean score of 40.29\%(which is equivalent to 4.83) in the years 2015 to 2017 nationally, and Nakuru County reported a mean score of 3.33 in 2015, a mean score of 2.81 in 2016 and a mean score of 3.00 in 2017. This implies that Nakuru County performed poorly in English Subject compared to the national performance in the subject. The low achievement of English Nationally and in Nakuru County doesn't portend well, for it limits the learners from realizing their full potentials, and the Kenyan Nation from achieving its development agenda as envisaged in vision 2030. This English Language Analysis report made manifest that the overall performance fell short of the ideal national mean of 50\% (mean score of 6.0 ) hence calling for innovation and creativity in teaching and preparing candidates for Examinations.

A lot of scholarly research articles have lauded the positive significant contributions of cooperative learning approach and its effect on students' academic achievement in various subjects around the world. These studies have showed a positive effect of cooperative learning approach in different contexts (Page (2017); Sharan (2018); Pandya (2017); Chebii, Wachanga, \& Anditi (2018)). However, there is much to be discovered such as techniques, and which CLA techniques have positive effects on what subjects. It's on this premise of persistently low achievement of English yearly that this study sought to fill the gap and examine the effect of incorporating cooperative learning approach on students' academic achievement in English in public coeducational secondary schools in Nakuru County.

\section{Objective of the Study}

The objective of the study was to establish the effect of cooperative learning approach on students' achievement in English in public co-education secondary schools in Nakuru, County Kenya.

\section{Hypothesis of the Study}

In order to achieve the above objectives, the following hypothesis guided the study;

H01: There is no statistically significant effect of cooperative learning approach on students' achievement of English in public co-educational secondary schools in Nakuru, County Kenya.

\section{Literature Review}

\section{Cooperative Learning Approach (CLA)}

Many efforts have been tried to expound on the meaning of cooperative or collaborative learning (CL). In a study that was done by Kagan and Kagan (2009) it was established that cooperative studying was an established fundamental form that was used with team challenges, reproduced in any learning environment. Furthermore, Yusuf,(2005) established that CLA activities had many functions in learning activities for instance it gave a lot of learners a chance to operate in cohorts, work and discuss in groups and ensured that all team members did everything from lesson planning and solving difficult challenges together. Johnson and Johnson (2000) noted that cooperate learning occurred even in large or huge classes of investigation and teaching in the discipline of education. They further asserted learning occurred when learners worked and operated together to arrive at group objectives (Johnson \& Johnson, 2000).

Slavin, (2016) established that there are five types of cooperative learning approaches, namely; student Teams - Achievement Divisions (STAD), Cooperative Integrated Reading and Composition (CIRC), Jigsaw, Group Investigation and Cooperative Scripting. Students teams-achievement division involved learners being put into small mixed ability level group of between 4 to 5 boys and girls and of all nationality. The instructor taught and the learners operated from their groups in order to ascertain that all were benefiting. Cooperative Integrated Reading and Composition (CIRC) are holistic educational activities tailored for instructing, reading and writing in the upper elementary grades (Slavin, 2014). Students work in groups of four members. Students interact with content among each other including reading to one another, summarizing stories to one another, decoding and mastering main ideas and other comprehension skills. 
For jigsaw, learners are slotted into a six member group to work and discuss on educational activities that were divided into smaller units for each member. Individual learners get an area in which they became experts, and learners of a similar area conglomerated in expert teams to deliberate and later got back to their initial groups to instruct what they studied with other team members. Group investigation is a full learning environment classroom where learners work in minimal groups and make use of collaborative investigation, group deliberation, and collaborative organization. Learners were fixed into groups of between two to six. The entire class listened to presentations from all the groups about their solutions to the challenge. Cooperative Scripting on the other hand learners take turns and present the condensed content to each other (Slavin, 2014). The current study used STAD in its pursuit of seeking the effect of cooperative learning approach on student's academic achievement in the English subject.

\section{Effects of Cooperative Learning Approach on Students' Academic Achievement}

In an exploratory study, Page (2017), which examined the barriers and enablers of the implementation of cooperate learning approach in New Zealand. The study established that teachers lacked better understanding of the structures of cooperative learning and this acted as a barrier to the implementation of cooperative learning in New Zealand. Other barriers were established to be poor social skills among the students and lack of enough time to create structures for cooperative learning creation of discussion groups. The enablers of cooperative learning on the other hand included initial and continuous teacher training on the use of the cooperative learning, development of social skills of learners and corroborations between teachers from different schools. The study noted that those schools that were able to apply cooperative learning approach were able to achieve higher academic mean scores as opposed to the rest. However the study presented a contextual research gap for it was done in New Zealand while the current study was done in a Kenyan Context.

Gull \& Shehzad (2015), carried out a study to examine the influence of cooperative learning approach in Education Subject in public colleges in Pakistan. The study found out that students who were taught using cooperative learning approach had a higher performance as compared to those who were taught using conventional methods in the Education subject in the college. The differences between the two groups were found to be statistically significant. The study recommended that cooperative learning to be used in public colleges in order to improve students' performance. While that study was carried out in Pakistan using college students the current study was done using high school students in Nakuru, Kenya.

Focusing on Science and Technology courses, Altun (2015), carried out a study to examine the effect of cooperative learning approach on students' academic achievement in middle level of education in Turkey. Using t-test, the study established that there were significant differences between the academic mean scores of students using conventional learning approaches and those using cooperating learning approaches. It was in respect to this established evidence that cooperative learning approach resulted to better academic achievement results as compared to those taught using conventional teaching methods. The reviewed study focused on Science and Technology courses while the current study focused on English Subject and therefore a conceptual research gap.

In a study conducted in Vietnam, Tran (2014), sought to compare the effectiveness of cooperative learning approach as compared to lecture-based approach in improving the performance of students in academic mean scores for Psychology Subject at Giang University. The study found out that the students taught using cooperative learning approach outperformed those taught using lecture-based approach. It was concluded that cooperative learning was more effective in improving the performance of students in Psychology Subject. Since the study was done at university level, there existed a research gap for a study to be done at secondary school level.

A study in United States of America by Sharan (2018), that sought to establish the gains brought about by cooperative learning approach. The study established that teaching using cooperative learning approach was preferred by teachers to other conventional methods of teaching. The respondents interviewed indicated that the use of cooperative learning approach improved the participation of students in academic activities and led to high academic mean scores by the students. Since the study by Sharan (2018), sought data from the teachers, there was need to get feedback from the students who are the recipients of the teaching approach and therefore the need to carry out the current study in Nakuru Kenya.

In India, Pandya (2017), carried out a study to examine the effect of the use of cooperative learning in teaching mathematics in secondary schools using quasi experimental approach. The study established that cooperative learning approach was more effective in enhancing critical thinking skills required in learning mathematics as compared to traditional methods of teaching in secondary schools in India. In respect to this, there were significant differences in the level of academic achievement in mathematics between the students taught using conventional methods and those taught using cooperative learning approach. The study recommended the use of cooperative learning approach in teaching Mathematics Subject in secondary schools in India. Since the reviewed study was done on mathematics, there existed a research gap for the current study to be done in English Subject. 
In Nigeria, Obinna-Akakuru, Onah, \& Opara (2015), carried out a study to examine the effect of cooperative learning approach on the performance of students in English test. The study established that there were significant differences in the mean scores in English test between the students using traditional methods of learning and those using cooperative learning approach. In respect to this, the study established that cooperative learning approach achieved high mean scores in the English test as compared to those using traditional methods. The study recommended that secondary schools should use cooperative learning approach and teachers trained on the use of the teaching approach.

A study by Chebii, Wachanga, and Anditi (2018), that sought to establish the effect of cooperative learning approach on the performance of students in Chemistry performance tests in secondary schools in Koibatek Sub-county. The study revealed that there were significant differences in the academic performance in Chemistry test between the students who were taught using the cooperative learning approach and those who were taught using conventional methods. The study concluded that cooperative learning was effective in improving students' performance in Chemistry subject in secondary school level. There however existed a research gap in this study for the study was done on Chemistry Subject while the current study was done on English test.

Conceptual Framework

Figure 2.1 shows the conceptualization of the study variables.

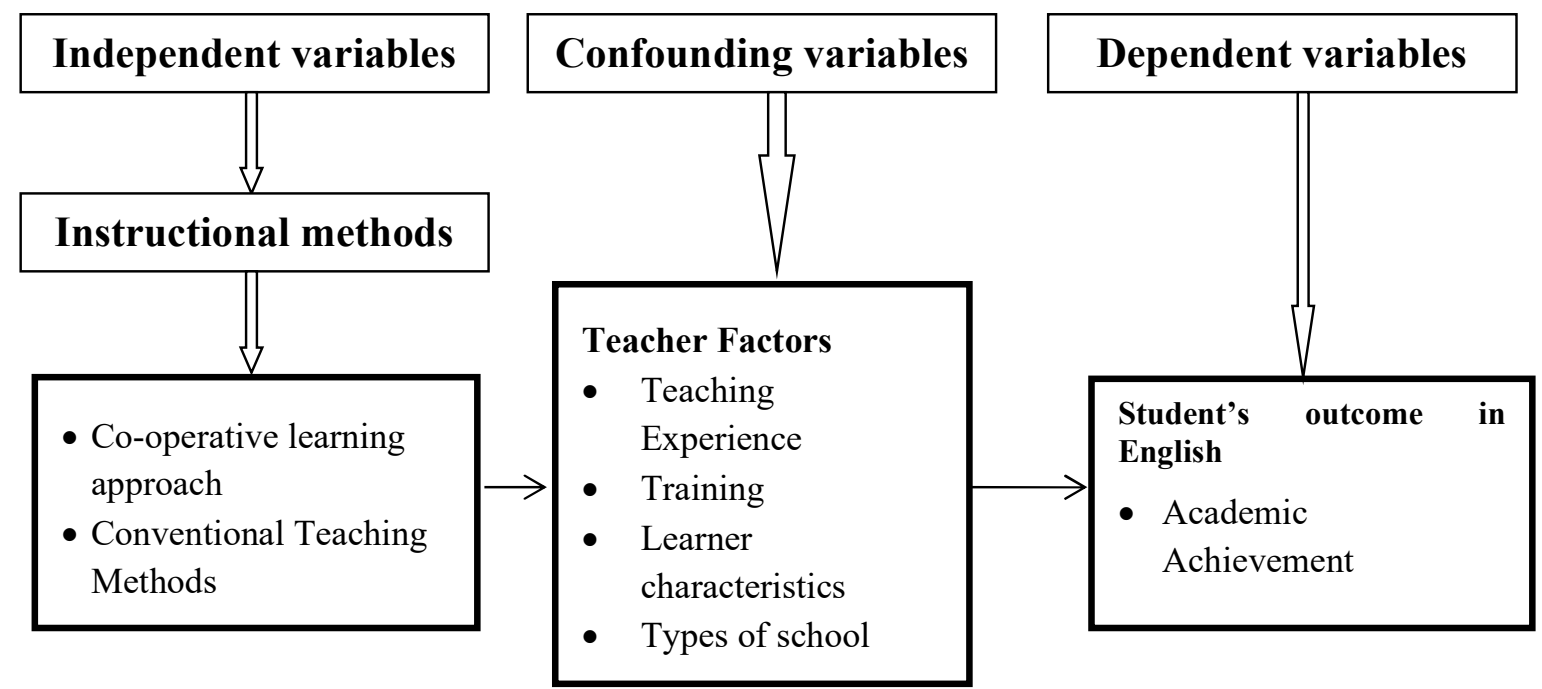

Figure 2.1: Conceptual Framework

\section{Research Methodology}

The study adopted quasi experimental design, based on Solomon Four- group, Non-equivalent Control Group Design. The study involved two Experimental groups, $E_{1}$ and $E_{2}$ which were taught through CLA method and two Control groups, $\mathrm{C}_{1}$ and $\mathrm{C}_{2}$ which were taught through the Conventional methods. The target populations were students and teachers from the four co-educational public secondary schools of Nakuru County. Since the study used Solomon Four Non-equivalent control Group Design, four co-educational public secondary schools were randomly selected from the five co-educational public secondary schools in Nakuru County. Two schools were randomly selected to be experimental groups while the other two as control groups and one for piloting.

The accessible population was 766 form three students in the four schools. From each of the school, the researcher then selected the class with the highest number of learners to participate in the study using purposive sampling. In addition to that, from each of the selected co-educational school, the study selected one senior teacher of English with the most experience in teaching using purposive sampling. The four teachers of English were the key informants of the study. The study sample size was 242 Form three students from the four coeducational public secondary schools in Nakuru County. The study used English Achievement Test (EAT) to collect quantitative data.

Data was analyzed using both descriptive and inferential statistics using the Statistical Package for Social Sciences (SPSS version 24). The hypotheses were tested using the following statistical tests for significance, t- test, ANOVA, ANCOVA. ANOVA and t- test were used to determine if there was any statistically significant effect on students' academic achievment in English between experimental and control 
groups. ANCOVA was used for statistical adjustment to enhance control if variation was evident in the experimental and control groups at the time of pre- testing. Qualitative data was coded into themes, interpreted and organized and a computer assisted qualitative data analysis (CAQDAS) package was used. The level of significance was computed at 5\% significant level in order to guide in the rejection or acceptance of the null hypothesis.

\section{Results and Discussion}

The objective of the study was to establish the effect of cooperative learning approach on students' academic achievement in English in public co-education secondary schools in Nakuru, County Kenya. The academic achievement in English was measured using an English Achievement Test (EAT). The scores in the English Achievement Test (EAT) ranged from 0-100. The test was administered six times; two times as a pre-test for two groups and four times as post-test for the four groups. The study found out that the experiment group E1 had a higher academic achievement in EAT as compared to that of the control groups. The study sought to test whether there was significant differences in the pre-test mean scores in Students' Achievement in English Test at 5\% significance level. This was done by the use of Independent Samples t-test as shown in Table 4.1.

Table 4.1: Independent Samples t-test of the Pre-test Scores of Students' Achievement in English Test

\begin{tabular}{lllccccc}
\hline Test & Group & N & Mean & SD & t-value & DF & P-value \\
\hline Achievement in & E1 & 71 & 57.5352 & 3.45101 & 3.375 & 127 & 0.001 \\
English Test & C1 & 58 & 55.4138 & 3.67082 & & & \\
\hline
\end{tabular}

The results for the independent samples t-test indicated that the differences in the pre-test mean scores in Students' Achievement in English Test were significant at 5\% significance level. The study further established that the mean scores for the post-test in EAT were different for the experimental groups and the control groups. The Experimental groups performed better in the EAT as compared to the control groups. To test whether the differences in the mean scores in English Achievement Test for the different groups were significant, the study used ANOVA and whose results are shown in Table 4.2.

Table 4.2: ANOVA of the Post-test Score on the Students' Achievement in English Test

\begin{tabular}{lccccc}
\hline & Sum of Squares & DF & Mean Square & F & Sig. \\
\hline Between Groups & 13864.856 & 3 & 4621.619 & 324.656 & 0.000 \\
Within Groups & 2932.501 & 206 & 14.235 & & \\
\hline Total & $\mathbf{1 6 7 9 7 . 3 5 7}$ & $\mathbf{2 0 9}$ & & & \\
\hline
\end{tabular}

The study revealed that there were significant differences in the post-test mean scores of the different groups in the study. This was due to the p-value being less than 0.05 and $F(3,206)=324.656$. However, the F-test of the ANOVA does not indicate which groups differ from the others and therefore the study carried out Post Hoc comparisons using Least Significant Difference (LSD). The results were presented in Table 4.3.

Table 4.3: Least Significant Difference (LSD) Post Hoc Comparisons of Students' Achievement in English Test Post-test Means for Four Groups

\begin{tabular}{ccccc}
\hline \multirow{2}{*}{ (I) Group } & (J) Group & Mean Difference (I-J) & Std. Error & Sig. \\
\hline \multirow{2}{*}{ E1 } & C1 & 16.02283 & 0.66779 & 0.000 \\
& E2 & 1.00419 & 0.76501 & $0.191(\mathrm{NS})$ \\
& C2 & 17.27753 & 0.72390 & 0.000 \\
E1 & E2 & -16.02283 & 0.66779 & 0.000 \\
& C2 & -15.01864 & 0.79384 & 0.000 \\
E1 & C1 & 1.25470 & 0.75430 & $0.098(\mathrm{NS})$ \\
& C2 & -1.00419 & 0.76501 & $0.191(\mathrm{NS})$ \\
& E1 & 15.01864 & 0.79384 & 0.000 \\
C2 & C1 & -16.27334 & 0.84159 & 0.000 \\
& E2 & -1.25470 & 0.72390 & 0.000 \\
\end{tabular}

${ }^{*}$ The mean difference is significant at the 0.05 level.

(NS) -Not Significant 
Focusing on the Post Hoc results for the pairwise comparisons, it was revealed that there were significant differences in the Students' Achievement in English Test, Post-test Means for the groups E1 and C1, E1 and C2, $\mathrm{C} 1$ and E1, C1 and E2, E2 and C1, E2 and C2, C2 and E1, and between groups C2 and E2. It was further revealed that there were no significant differences between groupsE1 and E2, C1 and C2, E2 and E1, and between groups $\mathrm{C} 2$ and $\mathrm{C} 1$. The study further sought to establish whether there are significant differences in the post-test mean scores of the combined groups (control and experimental). However since the pre-test results for the EAT between the control group and the experimental group were statistically significant $(\mathrm{t}(127)=3.375$, $\mathrm{p}<0.05$ ), (Table 4.1) the pre-existing differences before the treatment could have resulted to the observed posttest differences after the treatment. To control for the initial differences in the students' competencies in EAT between the two groups; the study used ANCOVA to standardize the post-test mean scores as shown in table 4.1. In the Analysis of the Covariance (ANCOVA), pre-test results for the E1 and E2 were used as the covariate and the results of the adjusted students' achievement in EAT presented in Table 4.4.

Table 4.4: ANCOVA Test Results Comparing Students' Achievement in English Test Post-test Mean Scores

\begin{tabular}{lccccc}
\hline & Sum of Squares & DF & Mean Square & F & P-value \\
\hline Pre-Test Scores & 1605.226 & 1 & 1605.226 & 32064.030 & 0.000 \\
Achievement in English & 5659.336 & 1 & 5659.336 & 113043.974 & 0.000 \\
Test & & & & & \\
Error & 6.308 & 126 & 0.050 & & \\
Total & $\mathbf{6 4 6 1 1 4 . 0 0 0}$ & $\mathbf{1 2 9}$ & & \\
\hline
\end{tabular}

The hypothesis of the study stating that there was no statistically significant effect of cooperative learning approach on public co-education secondary schools students' academic achievement in English in Nakuru, County Kenya was rejected. This is evidenced by the p-value being less than 0.05 and $\mathrm{F}(1,216)=113043.974$. The study therefore concluded that cooperative learning approach was effective in improving the academic achievement of the students in English test. The extent of the effect of the cooperative learning approach was evaluated using gain analysis as shown in Table 4.5.

Table 4.5: Gain analysis on Adjusted Students' academic achievement in English Mean Scores for $E_{1}$ and $\mathrm{C}_{1}$ Groups

\begin{tabular}{llcc}
\hline Stage & Scale & E1 & C1 \\
\hline \multirow{2}{*}{ Pre-Test } & $\mathrm{N}$ & 71 & 58 \\
& Mean & 57.5352 & 55.4138 \\
Post-Test & $\mathrm{N}$ & 71 & 58 \\
& Mean & 76.482 & 62.583 \\
\hline Mean Gain & & $\mathbf{1 8 . 9 4 6 8}$ & $\mathbf{7 . 1 6 9 2}$ \\
\hline
\end{tabular}

Students' academic achievement in English Pre-Test Mean Score for E1 was 57.5352 and after subjecting the students to cooperative learning approach, the post-test mean score was 76.482. This implied an increase of $18.95 \%$ in the student's achievement in English Test (EAT) when cooperative learning approach was used. On the other hand, the pre-test mean score for the $\mathrm{C} 1$ was 55.4138 and with continuous learning using conventional methods, the post-test mean score was 62.583. This represented an increase in the achievement with a margin of $7.17 \%$. Comparing the mean gain for the two groups of students', it was established that students using cooperative learning approach are likely to be $12 \%$ higher in English achievement test as compared to their peers who were taught using conventional methods.

\section{Conclusions}

In regard to the effect of cooperative learning approach on students' achievement in English in public coeducation secondary schools, the study concludes that there is statistically significant effect of cooperative learning approach on students' achievement of English in public co-educational secondary schools in Nakuru, County Kenya. The study further concluded that use of cooperative learning approach improves student achievement in English compared to use conventional methods.

\section{Recommendations}

The study recommended that English teachers should use cooperative learning approach (CLA) in teaching of English in secondary schools in Kenya. In respect to this, the study recommends in service training for teachers in regard to the use of cooperative learning approach and that Kenya Institute of Curriculum Development (KICD) to take into account and incorporate learner centered approaches such as cooperative learning approach 
as a method of teaching English in secondary schools, with an aim of improving students' achievement in English subject.

\section{References}

Barasa, M., \&Mutitu, J. (2013).The Relationship between Semantic functions and the Acquisition of English preposition. The IUP Journal of English Studies 3(1)-15-40.

Chebii, R., Wachanga, S. W., \& Anditi, Z. O. (2018). Effects of Cooperative E-Learning Approach on Students' Chemistry Achievement in Koibatek Sub-County, Kenya. Creative Education, 09(12), 1872-1880. https://doi.org/10.4236/ce.2018.912137

Gull, F., \& Shehzad, S. (2015). Effects of Cooperative Learning on Students' Academic Achievement. Journal of Education and Learning (EduLearn), 9(3), 246. https://doi.org/10.11591/edulearn.v9i3.2071

Johnson W. D, Johnson T. R \& Stanne B.M (2000). Cooperative Recording Methods, A meta- analysis. Peak Hall, SE: Minessota

Kagan, S. \& M. Kagan. (2009), Cooperative Learning School. Clemente, CA; Kagan Publishing.

Kenya National Examination Council (2018). English Language Analysis Report. Nairobi Kenya

Obinna-Akakuru, Onah, T. A., \& Opara, D. C. (2015). Cooperative Learning and Student's Academic Achievement in English Language in Imo State, Nigeria. IOSR Journal of Research \& Method in Education Ver, 5(3), 2320-7388. https://doi.org/10.9790/7388-05342629

Page, A. (2017). Implementing Cooperative Learning: A Consideration of Barriers and Enablers. Journal of Initial Teacher Inquiry, 3(7), 49-52.

Pandya, S. (2017). Interaction Effect of Co-Operative Learning Model and Students' Implicit Theory of Intelligence on Student Engagement in Mathematics. Asia Pacific Journal of Contemporary Education and Communication Technology (APJCECT), 3(1), 96-107.

Sharan, Y. (2018). Cooperative Learning for Academic and Social Gains: Valued Pedagogy, Problematic Practice. European Journal of Education, 45(2), 300-313. https://doi.org/10.1111/j.14653435.2010.01430.x

Slavin, R. (2014). Educational Psychology: Theory and Practice. 10th edn. Harlow: Pearson Educational Limited.

Slavin, R. E (2016). Educational Psychology - Theory and Practice. 11th Edition, New York.

Tombak, B. \&Altun, S. (2016). The Effect of Cooperative Learning: University Example. Eurasian Journal of Educational Research, 64, 173-196

Tran, V. D. (2014). The Effects of Cooperative Learning on the Academic Achievement and Knowledge Retention. International Journal of Higher Education, 3(2), 131-140. https://doi.org/10.5430/ijhe.v3n2p131

Yusuf, A. (2005). The Effect of Cooperative Instructional Strategy Students' Performance in Junior Secondary School Social Structures in ilorir, Nigeria. Nigeria Journal of Social Structures 1(2), 23-36. 